\title{
Genç Yetişkin Erkek Sporcuların Bireysel Yenilikçiliklerinin Bireysel Gelişim İnisiyatifleri Bağlamında İncelenmesi
}

\section{Çiğdem ÖNER ${ }^{*}$}

${ }^{1}$ İstanbul Gelişim Üniversitesi, Beden Eğitimi ve Spor Yüksekokulu, İstanbul, https://0000-0002-1939-0526

Orijinal Makale

Gönderi Tarihi: 18.05.2019
Kabul Tarihi: 26.06.2019
DOI: $10.30769 /$ usbd.567314

Online Yayın Tarihi: 30.06 .2019

\section{$\ddot{O} z$}

Bu çalışmada, genç yetişkin erkek sporcuların bireysel yenilikçilikleri ile bireysel gelişim inisiyatifleri arasındaki ilişkinin ve bireysel yenilikçiliğin bireysel gelişim inisiyatifi üzerindeki yordayıcı rolünün incelenmesi amaçlanmaktadır. İlişkisel tarama modelinin uygulandığı araştırmanın çalışma grubunu İstanbul'da yerleşik 350 genç yetişkin erkek sporcu oluşturmaktadır. Araştırmada, bireysel yenilikçilik düzeyinin saptanması için Hurt, Joseph ve Cook’un (1977) geliştirdikleri, Kılıçer ve Odabaşı'nın (2010) Türk kültürüne uyarladıkları Bireysel Yenilikçilik Ölçeği, bireysel gelişim inisiyatifinin ölçümlenmesinde ise Robitschek'in (1998) geliştirdiği, geçerlik ve güvenirliği Akın ve Anlı (2011) tarafından yapılan Bireysel Gelişim İnisiyatifi Ölçeği kullanılmıştır. Veri toplama aracı olarak, ayrıca Kişisel Bilgi Formu'ndan yararlanılmıştır. İstatistiksel analizler, SPSS 25.0 ile yapılmış, anlamlılık en az $p<0,05$ düzeyinde değerlendirilmiştir. Verilerin çözümlenmesinde betimsel istatistiklerin (Ortalama, Standart sapma, Ortanca, Frekans, Oran, En düşük değer, En yüksek değer) yanı sıra Kolmogorov Simirnov testi, Box plot grafikler, Student t-Testi, Pearson Korelasyon Analizi ve Lineer Regresyon analizi kullanılmıştır. Bulgulara göre; çalışma grubunu oluşturan genç yetişkin erkek sporcuların bireysel yenilikçilik düzeyleri düşük, bireysel yenilikçilik kategorileri sorgulayıcı nitelikte, bireysel gelişim düzeyleri ise ortanın biraz üzerindedir. Yapılan regresyon analizlerinde, bireysel gelişim inisiyatifi toplam puanı üzerine Bireysel Yenilikçilik Ölçeğinin fikir önderliği ve deneyime açıklık alt boyut puanlarının etkileri anlamlı bulunmuştur. Buna göre, fikir önderliği ve deneyime açıklığın bireysel gelişim inisiyatifinin yordayıcısı oldukları söylenebilir.

Anahtar kelimeler: Egzersiz ve spor psikolojisi, genç yetişkin erkek sporcular, bireysel yenilikçilik, bireysel gelişim inisiyatifi

\section{Investigation of Individual Innovativeness of Young Adult Male Athletes in Terms of Individual Development Initiative}

\begin{abstract}
In this study it is aimed to investigate the relationship between individual innovativeness and individual development initiatives of young adult male athletes and the predictive role of individual innovativeness on individual development initiative. The study group, in which the relational screening model was applied, consists of 350 young adult male athletes living in Istanbul. In order to determine the level of individual innovation the Individual Innovativeness Scale 'ISS' developed by Hurt, Joseph and Cook (1977) and adopted into Turkish culture by Kılıçer and Odabaşı was used. The Personal Development Initiative Scale, which was developed by Robitschek (1998) and adapted and validated by Akın and Anlı (2011), was utilized to measure the individual development initiative. In the study, the Personal Information Form was also used as a data collection tool. Statistical analyzes were performed with SPSS 25.0, and the significance was evaluated at least $p<0.05$. Descriptive statistics (Average, Standard deviation, Median, Frequency, Ratio, Lowest value, Highest value), as well as Kolmogorov Simirnov test, Box plot graphics, Student t-test, Pearson Correlation Analysis and Linear Regression Analysis were used in analyzing of the data. According to the findings; young adult male athletes have low levels of individual innovation, have 'early majority' innovativeness characteristics and their individual development initiative level is slightly above the average. In the regression analysis, the effects of the Individual Innovation Scale's opinion leadership and openness to experience subscale scores on the individual development initiative total score were found to be significant. Accordingly, it can be said that opinion leadership and openness to experience are predictors of individual development initiative.
\end{abstract}

Keywords: Exercise and sports psychology, young adult male athletes, individual innovativeness, individual development initiative

* Sorumlu Yazar: Çiğdem ÖNER, E-posta: esenlik@cigdemoner.com.tr 


\section{GÍRIȘ}

Güncel olanı içselleştirebilmenin, değişim yaratabilmenin, değişime özgü dinamikleri sürdürülebilir kılmanın yetkinliği belirleyici göstergeleri arasında değerlendirilen yenilikçilik, örgütsel olduğu kadar bireysel düzeyde de yüceltilen bir özellik olarak öne çıkmaktadır. Spor dünyasının çağın değişen ve gelişen görünümleri içinde endüstrileşmiş yapısı her düzeydeki sektör çalışanının yenilikçiliğini sorgularken, toplumun da rol model oluşturan konumları dolayısıyla genç yetişkin spor insanlarının yenilikçiliklerini bir değer olarak talep ettiği söylenebilir.

Gündoğdu ve Sunay'ın (2012:62) çalışmalarında yazıya dökülen; "Peki, niye yeniliğe ihtiyaç duyarız? Bireyi, toplumu, organizasyonları hangi şartlar yeniliğe zorlar?" sorgularında, Darwin'in "İnsan, hayatta kalmayı başaran, türlerin en güçlüsü veya en akıllısı değil, değişime en kolay ayak uyduranı" tanımına atıfta bulundukları, bu noktadan hareketle, dünya üzerindeki her şeyin hızla değiştiği ortamlarda yaşam süren insanın, insanın içinde bulunduğu her oluşumun, değişim karşısında ayakta kalabilmesini, rekabet edebilmesini yanıt olarak ele aldıkları görülmektedir. Araştırmacılara göre, var olabilmenin, rekabet edebilmenin kısacası başarılı olmanın anahtarı yenilik ve yenilik yapabilme bilincine sahip olabilmektir.

Diğer yandan, sporun içerik olarak "oyun” olma kavramının ötesine geçen boyutu, spor olgusunun içine katılan müsabakalı ya da müsabakasız her yeni bedensel ve veya zihinsel antrenman temelli etkinlikle daha da güçlü biçimde vurgulanmaktadır. Bu bağlamda, sporun ayırt edici temel unsuru olarak nitelendirilebilecek "rekabet" olgusunun, sektöre ivme katacak inovasyon uygulamalarını ve bu uygulamaları hayata geçirecek yetkinlikteki spor insanlarının alana hakimiyetlerini bir zorunluluk olarak spor yaşamının sahnesine yerleştireceği açıklıkla görülebilirdir. Dolayısıyla, spor dünyasının devingen ve ilerleyici içeriklerine uyumlanmak üzere yenilikçiliği benimsemeye doğru itilen spor insanlarının, sürdürülebilir kariyer yaşamı anlayışı çerçevesinde üst düzey gelişim odaklılıkları ile birlikte kendini yenileyen kariyer insanı olarak bireysel inisiyatif davranışı göstermelerinin bir gereklilik olduğu düşünülmektedir. $\mathrm{Bu}$ düşünceden yola çıkılarak gerçekleştirilen çalışmada, yapılan alanyazın taraması doğrultusunda sırasıyla bireysel yenilikçilik ve bireysel yenilikçiliğin bir koşutu olarak görülen bireysel gelişim inisiyatifi kavramları irdelenmiş, araştırmanın yöntemi açıklanmış, bulguların ortaya konulmasını takiben tartışma, sonuç ve öneriler sunulmuştur.

\section{Bireysel Yenilikçilik}

Bursalığlu'nun (2010) tanımında, daha önce tasarlanmış olanın kesin değişimi olarak nitelendirilen yenilikçilik (akt. Özgür, 2013:410), Hurt, Joseph ve Cook'a (1977:59) göre, bireyin değişime olan istekliliğidir.

Yenilikçilik kavramının dayanağını oluşturan yeniliğin yayılımı kuramı, aslen yeniliğin onaylanması veya kabul görmemesi süreci ile ilgilenmektedir. Bu kurama göre yenilik, Ünal'ın (2014:69) ifadesi ile bireyin yeni olarak algıladığı teknoloji, araç, gereç, fikir, nesne gibi farklı pek çok örnekten oluşabilmektedir. Beal ve Bohlen (1956, akt. Özata, 2009:28), 35 araştırmanın sonuçlarından yola çıkarak yayınladıkları raporlarında; yeniliklerin yayılmasına ilişkin iki önemli genelleme ortaya koymuşlardır. İlki, bireyin yeni fikirleri kabulünde birbirini izleyen 
beş aşamalı zihinsel bir sürecin işe koşulması, ikincisi ise bireylerin yeni fikirleri benimseme zamanları bağlamında bireysel ve sosyal özellikleri ile sınıflandırılabilmeleridir. Söz konusu beş aşamalı zihinsel sürecin bileşenleri sırasıyla; yenilik hakkında yüzeysel bilgiye sahip olunan farkındalık aşaması, yenilik hakkında detaylı bilginin edinildiği ve duyuşsal davranışın geliştirildiği ilgi aşaması, yeniliğin zihinsel açıdan değerlendirilerek "Yapabilir miyim?" sorusuna yanıt aranan değerlendirme aşaması, yeniliğin tecrübe edildiği deneme aşaması ve yeniliğin önemli ölçüde kullanımının sürdürülmesi kararı alınan benimseme aşamasıdır.

Yuan ve Woodman'a (2010:333) göre, bir yeniliği geliştirmek, benimsemek veya uygulamak bireysel yenilikçilik olarak tanımlanmaktadır. Toplumsal, kültürel değerler ve evrensel özellik taşıyan yaşam alanlarında, yaşantılanan değişikliklerle sağlıklı bir dengenin kurulması açısından önem taşıyan bireysel yenilikçilik anlayışı, kişinin yenilik karşısında risk alma, uyum gösterme, kabul etme, toleranslı olma ve yeniliğe ilişkin deneyimlere açık oluş durumlarını içermektedir (Adıgüzel, 2012; Kılıçer, 2011:23; Korucu ve Olpak, 2015).

Goldsmith ve Foxall (2003:324-325), bireylerin yeni olan karşısındaki tepkilerini karakterize eden farklılıklar olarak da değerlendirilebilecek bireysel yenilikçilik olgusunu kavramsallaştırmada üç farklı yaklaşım bulunduğunu açıklamış, bunları davranışsal, genel kişilik özelliği ve özel kişilik alanı özelliği yaklaşımları olarak sıralamışlardır. Rogers (1995:247), yeniliğin yayılmasında önemli olduğunu öne sürdüğü üç ana unsuru benimseme, benimseyenlerin ana rolleri ve ikisi arasındaki gözlenebilir tepkiler olarak nitelendirmiştir. $\mathrm{Bu}$ bağlamda yeniliğin yayılmasını dört temel öğeyi dikkate alarak yorumlamıştır. Bu öğeler, yeninin ne olduğu ve özelliklerinin incelendiği yenilik, yeniliğe ilişkin bilginin paylaşıldığ iletişism kanalları, yeniliğin anlık bir olaydan çok belli bir zaman diliminde oluştuğu, yenilik karar sürecinin açıklandığı zaman ve yeniliğin benimsenmesinde rol oynayan kişilerin ve yeniliğin kabulüne etki eden unsurların incelendiği sosyal sistemdir.

Rogers (1995; 2003), yenilikçiliği yeniliğin kabul ediliş biçimine göre beş kategoride ele almıştır;

a. Yenilikçi: Yeni düşünceleri tecrübe etme ve risk alma isteği olan, vizyon sahibi, atılgan, cesur, girişken, eğitimli, özgüvenli, bilgiye doğrudan ulaşma ve yenilikçi uygulamaları tanımak amacıyla seyahat eden, bilimselliğe değer veren, teknoloji kullanımında güçlü, üst düzey bilişsel becerileri olan, yardımsever, yeniliklerin yarattığ rahatlıkla karşılamayı bilen bireylerdir.

b. Öncü: Toplumun diğer bireylerine yenilikler hakkında bilgi aktaran, rehberlik ve yol göstericilik yapan, teknoloji odaklı, değişim taraftarı, değişimin yayılması ve ivme kazanmasına katkıda bulunan, vizyoner, risk alabilen, denemeye ve yeni deneyimlere istekli, saygıdeğer, dürüst insan olarak tanınan ve en önemlisi yenilik hakkındaki belirsizliği azaltan bireylerdir.

c. Sorgulayıcı: Yenilikler karşısında tedbirli ve temkinli tutum içinde olan, ölçülü, risk alma konusunda çekimser, ortalama yaş, ortalama eğitim ve ortalama sosyo-ekonomik düzeye yer alan, kitle iletişim araçlarından orta düzeyde yarar sağlayan, toplum içinde aktif katılım göstermekle birlikte nadiren liderlik konumunda görülen bireylerdir. Yeniliği kabulleri yenilikçi ve öncülere kıyasla daha uzun zaman alıp, yeniliği kabul biçimleri "ilk deneyen olma, sona da kalma" tarzındadır. 
d. Kuşkucu: Yenilikler karşısında şüpheci ve çekingen tavırlar sergileyen, toplumun çoğunluğunun yeniliği benimsemesini bekleyen, eğitim düzeyi düşük, yaş ortalaması yüksek, kitle iletişim araçlarından çok düşük düzeyde faydalanan, daha çok kişiler arası iletişimi seçen bireylerdir. Yeniliği kabullenmeleri için söz konusu yeniliğe ilişkin tüm normların açıkça belirlenmesi ve belirsizliklerin ortadan kalkmış olması gereklidir. $\mathrm{Bu}$ kişilerin yeniliğe açılmalarında akran baskısı önemli ölçüde etkili olmaktadır.

e. Gelenekçi: Değişime önyargıyla bakan, referans noktası olarak geçmişi alan, aldığı kararları geçmişte olanlara, yapılanlara göre belirleyen, dolayısıyla yeniliği kabullenme süreçleri yavaşlayan, yenilikleri benimsemede en geride kalan, yeniliği benimsemek için yeniliğin başka insanlarca tecrübe edilmesini ve sonuçların gözlemlenmesi için bekleyişte olan, teknolojiye ilişkin konularda gereğinden fazla desteğe gereksinen, risk almaktan kaçınan bireylerdir. Bu kişiler liderlik özelliği taşımamaktadırlar.

\section{Bireysel Gelişim İnisiyatifi}

Bireysel gelişim, psikolojik düşünme yönelimli bir kültürün mantıksal bir uzamıdır (Rimke, 2000:63). Bu bağlamda, sosyokültürel ve sosyoekonomik düzeneklerin farklılaşması ile kimliğini kendi kendine tasarlama, kendini yeniden yaratma yükümlülüğüne itilen günümüz insanı için yaşam boyu gelişim odağını korumak ve yanı sıra bireysel gelişim inisiyatifini kendi eline almak bir zorunluluk olmaktadır.

Foucault (1999:26), bireylerin kendi bedenleri, ruhları, düşünceleri, hareket biçimleri ve varoluş tarzları üzerinde kendi olanakları veya diğerlerinin yardımı ile bir dizi eylemde bulunmalarının, böylelikle belli bir ölçüde mutluluk, bilgelik, arınmışlık, kusursuzluk veyahut ölümsüzlük haline ulaşmak için kendilerini dönüştürmelerinin bir gereksinim şeklinde ortaya çıkmakta olduğunu açıklamaktadır.

Ivtzan ve arkadaşları (2013:915-929) bireysel gelişim olgusunun, kişilerin yaşam çizgileri boyunca çeşitli zorluk derecelerinde çok sayıda deneyimden geçtiği düşüncesine yoğunlaştığını bildirmişler ve psikolojik açıdan sağlıklı kalabilmenin bir koşulu olarak bireysel gelişim odağının süreklilik göstermesinin gerekliliğini öne sürmüşlerdir. Yarım (2004:19) bireysel gelişimi; insanın toplumsal yaşamın içinde özgür iradesi, bağımsızlığı ve özgür düşünebilme özelliklerini kaybetmeksizin, yaratıcı, üretici yeteneğini kullanarak olgun ve yeterli duruma gelmesi şeklinde yorumlamıştır. Ekşi'ye (2011:11-12) göre, bireysel gelişim kişinin bir başkasından yardım almadan davranışını değiştirmesi yahut diğer kişisel hedeflere ulaşmak için çabalaması olarak düşünülebilmektedir. Bir diğer söylemle bu, kişinin daha az iyi olduğu kabul edilen bir durumdan daha iyi olduğu düşünülen farklı bir duruma doğru olumlu yönde değişmesi süreci olarak da ifade edilebilir.

Tat (2007:149) bireysel gelişim kavramının, bir kişi ya da grubun ekonomik, entelektüel veya duygusal bağlamda gelişimini olanaklı kılan her durum ya da uygulamaya atıfta bulunduğunu belirtmektedir. Yine, Tat'a (2007:149) göre, bu kavram insanların yaşamlarının bir evresinde karşılaştıkları zihinsel veyahut hayatın ta kendisine ilişkin sorunların çözümüne odaklanmakta, dolayısıyla eğitim, iş yaşamı, psikolojik ve psikoterapötik alanlarda uygulama alanı bulmaktadır. Wright ve arkadaşları (2006) bireysel gelişimi; bireyin özünü kavradığı, 
farkındalık kazandığı bir süreç olarak nitelendirmekte, bu deneyimsel süreç sonucunda kişinin duygu, inanç, tutum ve davranışlarında değişim görüldüğüne işaret etmektedir.

Bireysel gelişim inisiyatifi yapısına ilk kez kavramsal bir nitelik kazandıran Robitschek (1998:184), kısaca bu yapıyı "bireysel gelişim sürecine aktif ve istendik katılım” olarak tanımlamaktadır. Robitschek’e (2003) göre, bu yapı bireysel gelişim inisiyatifinin kendi içinde bilişsel ve davranışsal yönleri olan bilişötesi bir nitelik içermektedir. Martin (2009:4,14) ise, değişimi isteme, değişim yönünde kendini güdüleme, arzu edilen ve amaçlanan değişimin süreci hakkında bilgi toplama ile değişim sürecine has öz yeterlilik algısının bu yapının bilişsel yönüne; değişim için bazı hedeflerin belirlenmesi, belirlenen hedefte ilerleme ve sonuçta hedefe ulaşmanın aynı yapının davranışsal yönüne örnek verilebileceğini vurgulamaktadır. Robitschek ve Keyes (2009:322), kişinin değişimi nasıl gerçekleştirebileceğini bilmesi ile değişimin olabilirliğine ilişkin taşıdığı inancın bilişsel, değişim sürecine kabul gösterip ilk adımı atmasının ise davranışsal bileşenlere örnek gösterilebileceğini belirtmişlerdir.

Şirin'e (2005:11) göre, kişisel gelişim insanın içindeki sınırsız gücü farkedip, varolan potansiyelinin içeriğini kavraması ve bu potansiyeli kullanabilmesidir. Bu bağlamda, kişisel gelişimin amacının bireyin potansiyel gücünün bileşenlerini kavrayarak, bunların karakteristik özelliklerine göre harekete geçmesini sağlaması olduğu söylenebilir. Özellikle, kişisel gelişimin ilgi ve etkinlik alanı içine, hedef belirleme, duyguların kontrolü, davranışların yönetimi, olumlu düşünüş ve hafıza teknikleri gibi konuların da dahil olduğu düşünüldüğünde sporcuların kişisel gelişimlerini yönlendirmedeki inisiyatiflerinin incelenmesi bir gereklilik olarak görülmektedir. Bireysel gelişim inisiyatifine sahip bir kişinin, bireysel gelişim odaklı deneyimleri araştırma, gelişmek için olası alanları saptama ve gelişim süreçlerini gözlemlemek için geçmiş, şimdi ve gelecek deneyimlerini eleştirel biçimde değerlendirebilme potansiyeli taşımakta (Martin, 2009:4; Robitschek, 2003:496) olduğuna ilişkin görüşler dikkate alındığında bir yönüyle performans sanatının eyleyicisi olan sporcuların bireysel gelişim inisiyatifi düzeylerinin incelenmesinin kaçınılmaz olduğu kanısı edinilmiştir. Buna bağlı olarak, genç yetişkin sporcuların yenilikçilik yönelimleri ile yenilikçilik algılarının güçlendirilmesi, düzenlenmesi ve yeniden çerçevelenmesinin bir gereklilik olduğu görüşü benimsenmiştir. Yanı sıra, bireysel yenilikçilikle birlikte var olan potansiyelin ortaya konması bakımından bireysel gelişim inisiyatifinin de sporcunun gerek mesleki ifadesi gerekse kariyer yönetimi açısından önem taşıdığı düşünülmektedir.

$\mathrm{Bu}$ çalışmada, yukarıda açıklanan görüşlerden hareketle izleyen sorulara yanıt aranmıştır;

a. Genç yetişkin erkek sporcuların bireysel yenilikçilik ve bireysel gelişim inisiyatifleri ile tanımlayıcı özellikleri (yaş, spor branşı, spor deneyimi, haftalık antrenman sıklığı) arasında anlamlı bir farklılık var midır?

b. Genç yetişkin erkek sporcuların bireysel yenilikçilik düzeyleri ve kategorileri nasıl bir dağılım göstermektedir?

c. Genç yetişkin erkek sporcuların bireysel yenilikçilik ve bireysel gelişim inisiyatifleri arasında anlamlı bir ilişki var mıdır?

d. Genç yetişkin erkek sporcuların bireysel yenilikçilikleri bireysel gelişim inisiyatiflerinin yordayıcısı mıdır? 


\section{YÖNTEM}

\section{Araştırma Modeli}

Bu çalışma, tarama modeli olarak tasarlanmış, ilişkisel bir araştırmadır. Karasar'ın (2016:114) bildirdiğine göre, ilişkisel tarama modelleri, iki ya da daha fazla sayıda değişken arasında birlikte değişimin varlığını ve/veya derecesini saptamayı araştıran modellerdir.

\section{Çalışma Grubu}

Araştırmanın çalışma grubunu, İstanbul İli Avcılar, Bağcılar ve Beylikdüzü İlçelerinde yaşamakta olan 18-28 yaş arası genç yetişkin erkek sporcular oluşturmaktadır. Basit seçkisiz örnekleme yöntemine dayandırılan çalışmada katılımcıların gönüllülük esası gözetilmiş, bireysel ya da takım sporları yapan toplam 350 genç yetişkin erkek sporcu çalışma kapsamına alınmıştır.

\section{Veri Toplama Araçları}

Araştırmada, Akın ve Anlı'nın (2011) geçerlik ve güvenirliklerini yaparak Türkçe'ye uyarladıkları Robitschek (1998) tarafından geliştirilen Bireysel Gelişim İnisiyatifi Ölçeği 'BGIÖ' (Personal Growth Initiative Scale 'PGIS') ile Hurt, Joseph ve Cook'un (1977) geliştirdiği, Kılıçer ve Odabaşı’nın (2010) Türkçe’ye uyarlama, geçerlik ve güvenirlik çalışmasını yaptığı Bireysel Yenilikçilik Ölçeği 'BYÖ' (Innovativeness Scale 'IS') kullanılmıştır. Ayrıca, veri toplama aracı olarak katılımcıların tanımlayıcı bilgilerini içeren Kişisel Bilgi Formu'ndan yararlanılmıştır.

\section{Kişisel Bilgi Formu}

Araştırmacı tarafindan hazırlanan kişisel bilgi formunda çalışmaya katılan bireylerin yaşları, uyguladıkları spor branşı, spor deneyim yılları ve haftalık çalışma sıklıklarına ilişkin bilgileri sorulmuştur.

\section{Bireysel Gelişim Inisiyatifi Ölçĕgi}

Bireysel Gelişim İnisiyatifi Ölçeği (BGİÖ), 6’lı Likert tipi derecelendirmeye dayalı ve 9 maddeden oluşan öz bildirim esası üzerine kurulu bir ölçme aracıdır. Ölçeğin maddeleri, "kesinlikle katılmıyorum (1)" ile "kesinlikle kattlıyorum (6)" arasında değerlendirilmektedir. Ölçekten alınabilecek en yüksek puan 54, en düşük puan ise 9 olmaktadır.

Tek boyutlu yapıya sahip bu ölçekten katılımcılar tarafından alınan yüksek puanlar kişilerin bireysel gelişim inisiyatifi düzeylerinin yüksek, düşük puanlar ise bireysel gelişim inisiyatifi düzeylerinin düşük olduğu yönünde yorumlanmaktadır.

\section{Bireysel Yenilikçilik Ölçeği}

Bireysel Yenilikçilik Ölçeği 'BYÖ' genel bağlamda yenilikçiliği ölçmekte, yenilikçi oluşu bireysel boyutta "yeni olanı denemeye isteklilik" olarak ele almaktadır (Hurt, Joseph ve Cook, 1977:59). Ölçek bireylerin yenilikçilik düzeylerini ve ait oldukları kategorileri kişilerin öz bildirimleri doğrultusunda belirleyen bir ölçme aracıdır. BYÖ, bireylerin; değişim ve yenilik karşısında duydukları kaygıyı açıklayan "Değişime direnç", ait oldukları grup içerisinde diğerlerinden önde oluş özellikleri yansıtan "Fikir önderliği", yeniliği arama ve deneme 
istekliliklerinin göstergesi olan "Deneyime açıklık" ile belirsizlikler karşısında yılmayıp güdülenmelerini ifade eden "Risk alma” olmak üzere dört alt boyuttan oluşmaktadır.

Ölçeğin özgün formunda, bireysel yenilikçiliği; yenilikçilikten gelenekselliğe doğru sıralanan beş değişik kategoride sınıflandırmayı olanaklı kılan toplam 20 ifade yer almaktadır. Bu esasa göre yapılan değerlendirmede; oluşan puan 80 puanın üzerinde ise bireyler "Yenilikçi", 69 ila 80 puan aralığında "Öncü”, 57 ve 68 puan arası "Sorgulayıcı", 46 ile 56 puan arası "Kuşkucu”, 46 puan altında ise "Gelenekçi" olarak tanımlanmaktadır.

Öte yandan, ölçek yardımıyla hesaplanan puan da genel olarak bireylerin yenilikçilik düzeyleri hakkında değerlendirmede bulunma amacıyla kullanılabilmektedir (Kılıçer ve Odabaşı, 2010:153). Buna göre; 68 ve üzeri puanlara sahip olan kişiler oldukça yenilikçi, 64 ve altı puan alanlar yenilikçilikte düşük olarak değerlendirilmekte, 65-67 puan aralığı ise orta düzeyde yenilikçilik olarak yorumlanmaktadır (Hurt, Joseph ve Cook, 1977; Demir Başaran ve Keleş, 2015:110). Ölçekte yer alan her bir ifade "Kesinlikle Katılmıyorum (1)" ile "Kesinlikle Katılıyorum (5)" aralığında puanlanan 5'li likert maddesi özelliği taşımaktadır. Ölçek, 12'si pozitif (1., 2., 3., 5., 8., 9., 11., 12., 14., 16., 18. ve 19. maddeler), 8'i negatif (4., 6., 7., 10., 13., 15., 17. ve 20. maddeler) ifadeden oluşmaktadır. Ölçekte yenilikçilik puanı; pozitif maddeleri toplam puanından negatif maddelerin toplam puanın çıkarılması ile elde edilen puana 42 eklenerek hesaplanmakta, dolayısıyla alınan en düşük puan 14, en yükseği ise 94 olmaktadır.

\section{Verilerin Analizi}

Verilerin analizinde IBM SPSS Statistics 25.0 istatistiksel analiz programından yararlanılmış, sonuçların yorumlanmasında anlamlılık düzeyleri .05, .01 ve .001 için sınanmıştır. Çalışma verileri değerlendirilirken tanımlayıcı istatistiksel yöntemlerin (ortalama, standart sapma, ortanca, frekans, oran, en düşük değer, en yüksek değer) yanı sıra dağılımın normallik testi Kolmogorov Simirnov tekniği ve box plot grafiklerle incelenmiştir. Normal dağılım göstermeyen nicel verilerin iki grup karşılaştırılması Mann Whitney U testi, ölçekler arası ilişkilerin belirlenmesi Spearman Korelasyon Analizi ile yapılmıştır. Çok değişkenli analizlerin değerlendirilmesinde Lineer Regresyon Analizi kullanılmıştır.

\section{BULGULAR}

Çalışmanın bu bölümünde istatistiksel analizler sonucunda elde edilen verilere ilişkin bulgu ve yorumlar sunulmuştur.

Çalışma grubunun tanımlayıcı özelliklerini gösteren veriler Tablo 1'de verilmiştir.

Tablo 1. Katılımcıların kişisel özelliklerine ilişkin tanımlayıcı istatistikler

\begin{tabular}{lll}
\hline Değişkenler & En düşük-En yüksek (Ortanca) & Ort \pm Ss \\
\hline Yaş (yıl) & $18-28(21)$ & $21,24 \pm 2,16$ \\
Spor deneyimi (yıl) & $1-19(8)$ & $7,99 \pm 3,78$ \\
Antrenman sıklığı (hafta/sayı) & $1-9(4)$ & $3,76 \pm 1,44$ \\
\hline
\end{tabular}

Tablo 1'e göre, genç erkek sporcuların yaşları 18 ila 28 arasında değişmekte, yaş ortalaması $21,24 \pm 2,16$ yıl olmaktadır. Katılımcıların spor geçmişleri incelendiğinde, deneyim sürelerinin

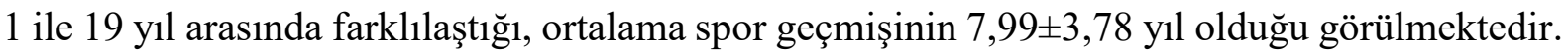


Ayrıca, grubun haftalık antrenman sıklığının 1 ile 9 arasında değiştiği, ortalamasının 3,76 olduğu izlenmektedir.

Çalışma grubunun katılımcılarının hangi takım ya da bireysel spora yönelmiş olduklarına göre ayrıntılandırılmış tanımlayıcı özellikleri Tablo 2'de sunulmuştur.

Tablo 2. Katılımcıların spor branşlarına ilişkin tanımlayıcı istatistikler

\begin{tabular}{cll}
\hline Spor Branşları & Sayı $(\mathbf{N})$ & Yüzde (\%) \\
\hline Takım sporları & $\mathbf{2 1 6}$ & $\mathbf{6 1 , 7}$ \\
Futbol & 137 & 39,1 \\
Basketbol & 38 & 10,8 \\
Hentbol & 17 & 4,9 \\
Voleybol & 24 & 6,9 \\
\hline Bireysel sporlar & $\mathbf{1 3 4}$ & $\mathbf{3 8 , 3}$ \\
Fitness & 17 & 4,9 \\
Tenis & 18 & 5,1 \\
Atletizm & 24 & 6,9 \\
Kickboks & 31 & 8,9 \\
Voleybol & 16 & 4,5 \\
Yüzme & 28 & 8,0 \\
\hline
\end{tabular}

Tablo 2, çalışma grubunun \%61,7'sinin $(\mathrm{n}=216)$ takım, \%38,3'ün $(\mathrm{n}=134)$ ise bireysel sporları yaptığını, katılımcıların \%39,1 (n=137) ağırlıkla futbol branşında olduğunu göstermektedir.

Çalışmada kullanılan Bireysel Yenilikçilik Ölçeği puanların dağılımları Tablo 3’te verilmiştir.

Tablo 3. Bireysel Yenilikçilik Ölçeği alt boyut ve toplam puanlarının dağılımları

\begin{tabular}{lcccc}
\hline & Madde sayısı & En Düşük-En Yüksek (Ortanca) & Ort \pm Ss & Cronbach's Alpha \\
\hline Değişime direnç & 8 & $1,5-5(3,9)$ & $3,79 \pm 0,68$ & 0,883 \\
Fikir önderliği & 5 & $2-5(4,2)$ & $4,19 \pm 0,57$ & 0,763 \\
Deneyime açıklık & 5 & $2,6-5(4,2)$ & $4,28 \pm 0,50$ & 0,753 \\
Risk alma & 2 & $1,5-5(4)$ & $3,83 \pm 0,81$ & 0,562 \\
\hline Bireysel Yenilikçilik & 20 & $41-84(61)$ & $61,63 \pm 6,70$ & 0,869 \\
\hline
\end{tabular}

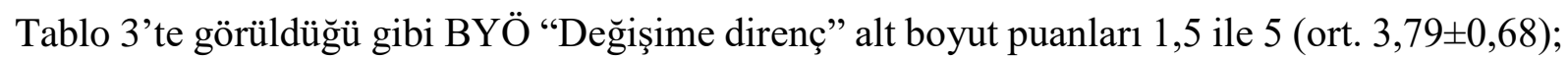

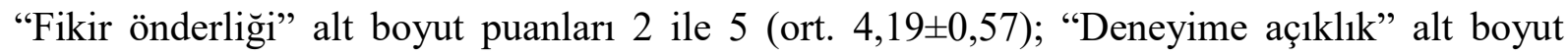
puanları 2,6 ile 5 (ort. 4,28 $\pm 0,50$ ) ve "Risk alma" alt boyut puanları 1,5 ile 5 arasında (ort. $3,83 \pm 0,81$ ) değişmekte, ölçekten elde edilen toplam puanlar 41 ile 84 arasında (ort. 61,63 $\pm 6,70$ ) seyretmektedir. Bireysel Yenilikçilik Ölçeği alt boyut Cronbach's Alpha katsayıları sırasıyla 0,$883 ; 0,763 ; 0,753 ; 0,562$, ölçek toplam puanına ilişkin Cronbach's Alpha ise 0,869 olarak hesaplanmıştır. Buna göre ölçeğin yüksek derecede güvenilir olduğu söylenebilir.

Bireysel Gelişim İnisiyatifi Ölçeği puanlarının dağılımları Tablo 4'te sunulmuştur. 
Tablo 4. Bireysel Gelişim İnsiyatifi Ölçeği toplam puanlarının dağılımları

\begin{tabular}{lcccc}
\hline & Madde sayısı & $\begin{array}{c}\text { En düşük-En Yüksek } \\
\text { (Ortanca) }\end{array}$ & Ort \pm Ss & Cronbach's Alpha \\
\hline Toplam puan & 9 & $12-54(44)$ & $43,11 \pm 7,53$ & 0,895 \\
\hline
\end{tabular}

Tablo 4'e göre, araştırmada kullanılan bir diğer ölçüm aracı olan BGİÖ'nin toplam puanları 12 ile 54 arasında değişmekte, ortalama değer 43,11, standart sapma değeri ise 7,53 olarak izlenmektedir. BGİÖ toplam puanının Cronbach's Alpha katsayısı 0,895 olarak hesaplanmıştır. Bulgular 1şığında ölçeğin yüksek derecede güvenilir olduğu söylenebilir.

Çalışma grubunun tanımlayıcı özelliklerine göre BYÖ alt boyut ve toplam puanları Tablo 5 'te sunulmuştur.

Tablo 5. Tanımlayıcı özelliklere göre Bireysel Yenilikçilik ve Bireysel Gelişim İnisiyatifi Ölçeklerine ilişkin puanların değerlendirilmesi

\begin{tabular}{|c|c|c|c|c|c|c|c|c|}
\hline & & & & Bireys & I Yenilikçil & Ölçeği & & $\begin{array}{l}\text { Bireysel Gelişim } \\
\text { İnisiyatifi Ölçeği }\end{array}$ \\
\hline & & $\mathrm{n}$ & $\begin{array}{l}\text { Değişime } \\
\text { direnç }\end{array}$ & $\begin{array}{l}\text { Fikir } \\
\text { önderliği }\end{array}$ & $\begin{array}{l}\text { Deneyime } \\
\text { açılık }\end{array}$ & Risk alma & Toplam & Toplam \\
\hline & & & Ort \pm Ss & Ort \pm Ss & Ort \pm Ss & Ort \pm Ss & Ort \pm Ss & Ort \pm Ss \\
\hline Yaş & $\mathrm{r}$ & 350 & $-0,030$ & $-0,046$ & $-0,033$ & $-0,063$ & $-0,022$ & 0,001 \\
\hline & $\mathrm{p}$ & & 0,573 & 0,392 & 0,541 & 0,243 & 0,677 & 0,998 \\
\hline Spor & Takım & 216 & $3,80 \pm 0,64$ & $4,20 \pm 0,59$ & $4,26 \pm 0,51$ & $3,81 \pm 0,80$ & $61,58 \pm 6,81$ & $43,22 \pm 7,46$ \\
\hline & Bireysel & 134 & $3,79 \pm 0,73$ & $4,16 \pm 0,54$ & $4,31 \pm 0,49$ & $3,85 \pm 0,83$ & $61,72 \pm 6,55$ & $42,94 \pm 7,66$ \\
\hline & ${ }^{a} \mathrm{p}$ & & 1,000 & 0,532 & 0,361 & 0,620 & 0,844 & 0,734 \\
\hline Spor & $\mathrm{r}$ & 350 & $-0,027$ & 0,033 & 0,002 & 0,033 & 0,045 & 0,074 \\
\hline $\begin{array}{l}\text { Deneyimi } \\
\text { (y1l) }\end{array}$ & $\mathrm{p}$ & & 0,611 & 0,542 & 0,972 & 0,537 & 0,404 & 0,168 \\
\hline 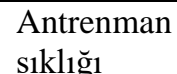 & $\mathrm{r}$ & 350 & $-0,066$ & $-0,016$ & $-0,059$ & 0,015 & 0,029 & 0,038 \\
\hline (hafta/sayı) & $\mathrm{p}$ & & 0,217 & 0,768 & 0,274 & 0,773 & 0,592 & 0,482 \\
\hline
\end{tabular}

${ }^{a}$ Student $t$ Test

Tablo 5'te izlendiği gibi, çalışma grubuna ilişkin tanımlayıcı özelliklerden yaş, spor branşları, spor deneyimi ve antrenman sıklığı ile gerek Bireysel Yenilikçilik Ölçeği alt boyut ve toplam puanları gerekse Bireysel Gelişim İnsiyatifi Ölçeği toplam puanı arasında istatistiksel olarak anlamlı farklılık belirlenmemiştir $(\mathrm{p}>0,05)$.

Çalışma grubunun bireysel yenilikçilik düzeylerine ilişkin dağılımları Tablo 6'da verilmiştir.

Tablo 6. Bireysel yenilikçilik düzeylerine göre tanımlayıcı istatistikler

\begin{tabular}{llll}
\hline Yenilikçilik Puanı & Yenilikçilik Düzeyi & Sayı (n) & Yüzde (\%) \\
\hline 64 ve altı & Yenilikçilikte düşük & 223 & 63,7 \\
65-67 & Orta düzeyde yenilikçi & 81 & 23,2 \\
68 ve üstü & Oldukça yenilikçi & 46 & 13,1 \\
\hline Toplam & & 350 & 100,0 \\
\hline
\end{tabular}


Tablo 6'ya göre, çalışma grubunun katılımcısı 64 ve altı puan alan $223(\% 63,7)$ genç yetişkin erkek sporcunun bireysel yenilikçilik düzeyi düşük seyretmektedir. Bulgulardan, 65-67 arası puan alan $81(\% 23,2)$ genç yetişkin erkek sporcunun orta düzeyde yenilikçi, $46(\% 13,1)$ genç yetişkin erkek sporcunun ise oldukça yenilikçi olduğu görülmektedir.

Çalışma grubunun katılımcılarının bireysel yenilikçilik kategorilerine ilişkin dağılımları ayrıca incelenmiş, sonuçlar Tablo 7'de aktarılmıştır.

Tablo 7. Bireysel yenilikçilik kategorilerinin dağılımları

\begin{tabular}{lll}
\hline & Sayı (n) & Yüzde (\%) \\
\hline Gelenekçi & 3 & 0,9 \\
Kuşkucu & 64 & 18,3 \\
Sorgulayıcı & 237 & 67,7 \\
Öncü & 40 & 11,4 \\
Yenilikçi & 6 & 1,7 \\
\hline
\end{tabular}

Bireysel Yenilikçilik Ölçeği toplam puanlarına göre, çalışmaya katılan genç yetişkin erkek sporcuların 3'ü $(\% 0,9)$ gelenekçi, 64'ü $(\% 18,3)$ kuşkucu, 237'si $(\% 67,7)$ sorgulayıcı, 40'1 $(\% 11,4)$ öncü ve 6’sı $(\% 1,7)$ yenilikçidir (Tablo 7).

Yapılan analizlerde Bireysel Yenilikçilik Ölçeği ile Bireysel Gelişim İnisiyatifi Ölçeği arasındaki ilişki de incelenmiş, elde edilen sonuçlara Tablo 8'de yer verilmiştir.

Tablo 8. Bireysel Yenilikçilik Ölçeği alt boyut ve toplam puanları ile Bireysel Gelişim İnisiyatifi Ölçeği toplam puanlarının ilişsisi

\begin{tabular}{|c|c|c|c|c|c|c|}
\hline & & \multicolumn{4}{|c|}{ Bireysel Yenilikçilik Ölçeği } & \multirow[b]{2}{*}{ Toplam } \\
\hline & & $\begin{array}{l}\text { Değişime } \\
\text { Direnç }\end{array}$ & $\begin{array}{l}\text { Fikir } \\
\text { Önderliği }\end{array}$ & $\begin{array}{l}\text { Deneyime } \\
\text { Açıklık }\end{array}$ & Risk Alma & \\
\hline \multirow{2}{*}{$\begin{array}{l}\text { Bireysel Gelişim } \\
\text { İnisiyatifi Ölçeği }\end{array}$} & $\mathrm{r}$ & $-0,141$ & 0,464 & 0,464 & 0,223 & 0,310 \\
\hline & $\mathrm{p}$ & $0,008^{* * *}$ & $0,001 * *$ & $0,001^{* * *}$ & $0,001^{* *}$ & $0,001 * *$ \\
\hline
\end{tabular}

r:Pearson Korelasyon Katsayısı

Tablo 8'e göre Bireysel Gelişim İnsiyatifi Ölçeği puanları ile Bireysel Yenilikçilik Ölçeği değişime direnç ile negatif, fikir önderliği, deneyime açıklık, risk alma puanları ve toplam puanlar arasında pozitif yönlü istatistiksel olarak anlamlı ilişki bulunmuştur (sırasıyla r:-0,141; r:0,464; r:0,464; r:0,223; r:0,310; $\mathrm{p}<0,01)$.

Bireysel Yenilikçilik Ölçeği değişime direnç, fikir önderliği, deneyime açıklık, risk alma alt boyut puanlarının tek değişkenli analizinde, Bireysel Gelişim İnsiyatifi Ölçeği toplam puanı üzerine ayrı ayrı etkili risk faktörleri oldukları görülmektedir (Tablo 8). Ölçekler arası çok değişkenli etkileri göstermek için Lineer Regresyon analizi uygulanmıştır.

Bireysel Yenilikçilik Ölçeği alt boyut puanlarının Bireysel Gelişim İnsiyatifi Ölçeği toplam puanları üzerine etki derecelerini gösteren model özeti Tablo 9'da sunulmuştur. 
Tablo 9. Model Özeti

\begin{tabular}{ccccc}
\hline Model & R & R Kare & Düz. R Kare & Std. Hata \\
\hline 1 & 0,502 & 0,252 & 0,243 & 6,55 \\
\hline
\end{tabular}

Tablo 9'a göre $\left(\mathrm{R}^{2}=0,252\right)$ Bireysel Yenilikçilik Ölçeği alt boyut puanları, Bireysel Gelişim İnsiyatifi Ölçeği toplam puanlarını \%25,2 oranında açıklamaktadır.

Bireysel Yenilikçilik Ölçeği alt boyut puanlarının Bireysel Gelişim Ölçeği toplam puanları üzerine etkileri regresyon analizi yardımıyla test edilmiş olup, analiz bulguları Tablo 10'da sunulmuştur.

Tablo 10. Bireysel Yenilikçilik Ölçeği alt boyut puanlarının Bireysel Gelişim Ölçeği toplam puanları üzerine etkisinin regresyon analizi

\begin{tabular}{|c|c|c|c|c|}
\hline \multirow[b]{2}{*}{ Model } & \multirow{2}{*}{$\begin{array}{c}\text { Standardize } \\
\text { Edilmemiş } \\
\text { Katsayılar }\end{array}$} & \multirow[t]{2}{*}{$p$} & \multicolumn{2}{|c|}{ B için \%95 Güven Aralığı } \\
\hline & & & Alt Sinır & Üst Sınır \\
\hline Değişime Direnç & $-0,054$ & 0,922 & $-1,133$ & 1,026 \\
\hline Fikir önderliği & 3,521 & $0,001 * *$ & 1,761 & 5,281 \\
\hline Deneyime açıklık & 3,820 & $0,001 * *$ & 1,701 & 5,940 \\
\hline Risk alma & 0,468 & 0,315 & $-0,446$ & 1,383 \\
\hline
\end{tabular}

Anlamlılık sütunundaki değerden $(\mathrm{F}=29.077, \mathrm{p}=0,001 ; \mathrm{p}<0,01)$ bahis konusu değişkenler aras1 ilişkinin istatistiksel olarak anlamlı bulunduğu anlaşılmaktadır. Yapılan regresyon analizi sonucunda bireysel yenilikçiliğin fikir önderliği ve deneyime açıklık değişkenlerinin modele anlamlı etkileri olduğu görülmektedir $(\mathrm{p}<0,01)$.

\section{TARTIŞMA VE SONUÇ}

Bu çalışmada, sporun sosyo-psikolojik açıdan incelenmesinde katkı sağlayabileceği düşünülen bireysel yenilikçilik ile bireysel gelişin inisiyatifi temasının genç yetişkin erkek sporcular çerçevesinde irdelenmesi, bireysel yenilikçiliğin alt bileşenleri olarak değişime direnç, fikir önderliği, deneyime açıklık ve risk alma ile bireysel gelişim inisiyatifi arasındaki ilişkilerin incelenmesi amaçlanmıştır.

$\mathrm{Bu}$ amaçla yürütülen araştırmanın çalışma grubunu İstanbul ili Avcılar, Bağcılar ve Beylikdüzü'nde yaşamakta olan genç yetişkin erkek sporcular oluşturmuştur. Çalışmada ulaşılan sonuçlara göre; çalışma grubunu oluşturan genç yetişkin erkek sporcuların bireysel yenilikçilik düzeyleri düşük, bireysel yenilikçilik kategorileri sorgulayıcı nitelikte, bireysel gelişim düzeyleri ise ortanın biraz üzerinde izlenmektedir.

Araştırmada, çalışma grubuna ilişkin tanımlayıcı özelliklerden yaş, spor branşları, spor deneyimi ve antrenman sıklığının Bireysel Yenilikçilik Ölçeği alt boyut ve toplam puanlarının yanı sıra Bireysel Gelişim İnsiyatifi Ölçeği toplam puanına göre yapılan değerlendirilmesinde istatistiksel açıdan anlamlı farklılıklar bulunmamıştır. 
Mülhim (2018), Bartın Üniversitesi Beden Eğitimi ve Spor Yüksekokulu öğrencileri örneğinde yürüttüğü çalışmada katılımcıların BYÖ puan ortalamalarının cinsiyet, öğrenim görülen bölüm, sınıf, ikamet, lise türü, gelir değişkenlerine göre istatistiksel açıdan anlamlı bir farklılık gösterirken; baba eğitim durumu, anne eğitim durumu ve aktif (lisanslı) spor yapıyor olma değişkenlerine göre anlamlı farklılık bulunmadı̆̆ını saptamıştır. Tırpan (2016) ise yine beden eğitimi ve spor yüksekokulu öğrencileri üzerinde yaptığı çalışmada, bireysel yenilikçiliğin yaş, öğrenim görülen bölüm, sınıf düzey ile anlamlı bir ilişki içinde bulunmadığını, cinsiyetleri, öğrenim gördükleri üniversite ve bölüm programları ile istatistiksel olarak anlamlı bir ilişki içinde olduklarını, cinsiyet değişkenine göre yalnız değişime direnç alt boyutunda anlamlı bir farklılık bulunduğunu; erkek öğrencilerin kadın öğrencilere göre değişime direnç alt boyutunda daha yüksek ortalama değerlere sahip olduğunu ortaya koymuştur.

$\mathrm{Bu}$ araştırmanın bulguları, genç yetişkin erkek sporcuların bireysel yenilikçilik özelliklerinin sorgulayıcı kategoride olduğunu ortaya koymaktadır. Buna göre, genç yetişkin erkek sporcuların yenilikçilik eğilimlerinin; bir yeniliği kabullenmeleri öncesinde bireysel ya da toplumsal düzlemde denenmiş olmasını önceliklendiren bir yapıda olduğu, bir diğer ifade ile sınanmışlığın görünür kıldığı yararlılığın ikna edici sonuçları ile olumlu ilgi, tutum, yaklaşım ve hatta olumlu yargı geliştirme yönünde seyrettiği söylenebilir. Bu noktadan hareketle, genç yetişkin erkek sporcuların yenilikçilik arayışlarına temkinli oluş halinin eşlik ettiği nispeten 1lımlı bir isteklilik içinde oldukları düşünülmektedir.

$\mathrm{Bu}$ çalışmada yenilikçilik kategorilerine ilişkin elde edilen bulgular, alanyazında farklı disiplinlerde farklı gruplarla yürütülen çalışmaların (Kayabaş ve Aydın, 2019; Akça ve Şakar, 2018; Demircioğlu, Konokman ve Akay, 2016; Demir Başaran ve Keleş, 2015; Korucu ve Olpak, 2015; Örün ve ark., 2015; Yılmaz Öztürk ve Summak, 2014; Kılıçer ve Odabaş1, 2013; Çuhadar, Bülbül ve Ilgaz, 2013; Özgür, 2013) yanı sıra spor bilimleri alanında, Mülhim'in (2018) Bartın Üniversitesi Beden Eğitimi ve Spor Yüksekokulu öğrencileri, Tırpan ve Gençer'in (2018) Beden Eğitimi ve Spor Yüksekokulu öğrencileri, Atalay’ın (2018) Gençlik Hizmetleri ve Spor İl Müdürlüğü çalışanları, Karadağ'ın (2018) spor federasyonu çalışanları, Çengel'in (2016) spor tüketicileri, Ünal'ın (2014) Muğla S1tkı Koçman Üniversitesi Beden Eğitimi ve Spor Yüksekokulu öğrencileri, Atalı ve Sertbaş’ın (2013) Kocaeli bölgesindeki futbol hakemleri ile yaptıkları çalışmalarla benzerlik göstermektedir. İşaret edilen çalışmaların tamamında katılımcıların bireysel yenilikçilik kategorilerinin "sorgulayıcı" nitelik taşıdığı belirlenmiştir.

Ayrıca, bireysel yenilikçilik düzeyi esas alınarak yapılan alanyazın taramasında, bazı araştırma bulgularının bu çalışmanın sonuçları ile benzerlik gösterdiği, katılımcıların bireysel yenilikçilik düzeylerinin düşük bulunduğu tespit edilmiştir (Aslan, 2017; Demiralay, Bayır ve Gelibolu, 2016; Kılıç, 2015; Kılıç ve Tuncel, 2014). Bununla birlikte, farklı disiplinlerde yürütülen bazı çalışmalarda ise katılımcıların bireysel yenilikçilik düzeylerinin bu araştırmanın sonuçlarından farklı olarak yüksek bulunduğu saptanmıştır (Akgün, 2017; Yeğin, 2017; Söylev, 2016, Demir Başaran ve Keleş, 2015; Y1lmaz Öztürk ve Summak, 2014; Özgür, 2013; Kılıçer, 2011). Ayrıca, bizim çalışmamızdan farklı olarak Mülhim'in (2018) çalışmasında, araştırmaya katılan beden eğitimi ve spor yüksekokulu öğrencilerinin bireysel yenilikçilik puanlarına göre değerlendirilmesinde \%56,4'ünün yüksek düzeyde yenilikçi olduğu bulunmuştur. 
Bireysel yenilikçilik ölçeği puanlarının bireysel gelişim inisiyatifi ölçeği puanı ile ilişkisi incelendiğinde; bireysel gelişim inisiyatifi ile değişime direnç alt boyutu arasında negatif, fikir önderliği, deneyime açıklık, risk alma puanları ve bireysel yenilikçilik toplam puanları arasında pozitif yönlü istatistiksel olarak anlamlı ilişki saptanmıştır. Buna göre, genç yetişkin erkek sporcuların bireysel gelişim inisiyatifleri arttıkça değişime dirençlerinin azaldığı, bununla beraber fikir önderlikleri, deneyime açıklıkları, risk almaları ve genel olarak bireysel yenilikçiliklerinin arttığı ifade edilebilir. Elde edilen bulgulardan yola çıkarak, genç sporcuları yönlendiren tüm kamu ve özel spor kurum ve kuruluşlarının spor branşlarına özgü değerleri korurken, eski ve işe yararlılığ yitirilmiş konuları, kuralları ve yapıları dönüştürmelerinin bir gereklilik halini aldığı söylenebilir.

Rogers (2003), bireysel yenilikçiliğin alt kategorilerinin her birinde yenilikçiliği benimseme hızını tetikleyen veya yavaşlatan unsurların sosyo ekonomik değişkenler, kişisel değişkenler ve iletişim olduğunu bildirmiştir. Rogers'1n (2003) sosyo ekonomik özelliklerden eğitimin yenilikçiliğin benimsenme hızına olumlu katkı sağladığı görüşünü teyit eden bir bulgu, Karadağ'ın (2018) çalışmasında görülmektedir. $\mathrm{Bu}$ çalışma sonuçlarına göre, spor federasyonları çalışanlarının bireysel yenilikçilik eğilimleri, "yenilikçilikte düşük" ve "yenilikçi" olarak sınıflandırıldığında lisansüstü mezunlarının "yenilikçi" olma miktarı yüzdesel olarak diğer eğitim düzeyleri olan lisans ve orta eğitim mezunlarının yenilikçilik miktarına göre daha yüksek olduğu gibi, yenilikçiliği benimseme eğilimi de eğitim düzeyinin düşmesine bağlı olarak yüzdesel olarak gerilemektedir.

Açıkgöz Ersoy ve Muter Şengül'e (2008:65,59) göre, yenilikçiliğin oluşması, gelişmesi, yayılması ve başarısında gerek yaratıcısı gerekse kullanıcısı insan olduğu için; bilgi, öğrenme ve eğitimin özel bir yeri bulunmaktadır. Bu hususa istinaden araştırmacılar, özellikle kamusal alanda yenilikçi uygulamaların geliştirilmesi ve yayılmasında çağdaş eğitim kurumları ile iyi bir eğitim-öğretim sunulmuş eğitimcilerin önemini vurgulamakta, ayrıca ülkede yenilikçilik için gereken uygun ortam ve koşulların oluşturulması gereğine işaret etmektedir.

Tüm bunlardan hareketle, gerek Spor Bilimleri Fakülteleri ile Beden Eğitimi ve Spor Yüksekokulları lisans gerekse meslek yüksek okulları bünyesindeki spor yönetimi ön lisans programlarında yenilikçilik odaklı yönetim ve liderlik modellerinin tanıtılması, yenilikçi spor teknoloji ve uygulamalarının yerinde gözlem ve yaşantısal öğrenme metodları ile aktarılması, ders içeriklerinin yenilikçi yönelimli dünya konjonktürünü yakalayabilme amacıyla iç dokuları ile yeniden gözden geçirilmesi, ayrıca spor federasyonlarının antrenörlük/eğitmenlik/hakemlik kursları ve kademeler arası gelişim seminerlerinde yeni nesil sporcuların ve sporun liderlerinin yenilikçiliklerini ve bireysel gelişim inisiyatiflerini destekleyen içeriklerle eğitim programlarını güncellemeleri, böylelikle spor dünyasının genç insanlarını kendi kariyerini yönetme becerisini taşıyan bireyler olarak yetişebilmeleri üzere güçlendirmeleri önerilmektedir.

\section{KAYNAKLAR}

Açıkgöz Ersoy, B., ve Muter Şengül, C. (2008). Yenilikçiliğe yönelik devlet uygulamaları ve AB karşılaştırması. Yönetim ve Ekonomi, 15(1), 59-74.

Adigüzel, B. (2012). Inovasyon ve inovasyon yönetimi: Steve Jobs örneği. Yüksek lisans tezi, Gazi Üniversitesi Sosyal Bilimler Enstitüsü, Ankara. 
Akça, F., ve Şakar, Z. (2018). Öğretmen adaylarının bireysel yenilikçilik düzeylerinin incelenmesi. İçinde Ö. Demirel ve S. Dinçer. (Eds). Küreselleşen Dünyada Eğitim (Ss. 451-462). DOI: 10.14527/9786053188407.29.

Akgün, F. (2017). Investigation of instructional technology acceptance and individual innovativeness of academicians. Turkish Online Journal of Qualitative Inquiry, 8(3), 291-322.

Akın, A., ve Anlı, G. (2011). Bireysel gelişim inisiyatifi ölçeğinin Türkçeye uyarlanması: geçerlik ve güvenirlik çalışması. Mersin Üniversitesi Eğitim Fakültesi Dergisi, 7(1), 42-49.

Aslan, E. (2017). Kırsal turizmde yenilik ve kırsal turizm işletmecilerinin bireysel yenilikçilik düzeylerinin çeşitli değiş̧kenler (katılımcılara ve işletmelere iliş̧kin) açısından incelenmesi: kocaeli/kartepe örneği. Yüksek lisans tezi, Kırklareli Üniversitesi Sosyal Bilimler Enstitüsü, Kırklareli.

Atalay, A. (2018). Gençlik Hizmetleri ve Spor İl Müdürlüğü çalışanlarının bireysel yenilikçilik düzeyi. Electronic Turkish Studies, 13(10), 87-108.

Atal1, L., \& Sertbaş, K. (2013). A research on individual innovativeness levels of football referees (Kocaeli region case). Turkish Journal of Sports and Exercise, 15(3), 18-21.

Baloğlu, B., ve Davutoğlu A. (2009). Sporun değişen yüzü. İstanbul : Derin Yayınevi.

Beal, G.M., \& Bohlen, J.M. (1956). The diffusion process. Farm Foundation, Increasing Understanding of Public Problems and Policies, 111-121.

Bursalığlu, Z. (2010). Okul yönetiminde yeni yapı ve davranış. Ankara: Pegem Akademi.

Çengel, O. (2016). Spor tüketicilerinin bireysel yenilikçilik ve alışveriş davranış biçimleri arasındaki ilişkinin incelenmesi. Yüksek lisans tezi, Muğla Sıtkı Koçman Üniversitesi Sağlık Bilimleri Enstitüsü, Muğla.

Çuhadar, C., Bülbül, T., ve Ilgaz, G. (2013). Öğretmen adaylarının bireysel yenilikçilik özellikleri ile teknopedagojik eğitim yeterlilikleri arasındaki ilişkinin incelenmesi. İlköğretim Online, 12(3), 797-807.

Demir Başaran, S., ve Keleş, S. (2015). Yenilikçi kimdir? Öğretmenlerin yenilikçilik düzeylerinin incelenmesi. Hacettepe Üniversitesi Ĕgitim Fakültesi Dergisi, 30(4), 106 -118.

Demiralay, R., Bayır, E.A., ve Gelibolu, M.F. (2016). Öğrencilerin bireysel yenilikçilik özellikleri ile çevrimiçi öğrenmeye hazır bulunuşlukları ilişkisinin incelenmesi. Eğitim ve Öğretim Araş̧tırmaları Dergisi, 5(1), 161-168.

Demircioğlu, T., Konokman, G.Y., ve Akay, C. (2016). Eğitim fakültesi öğretim elemanlarının yenilikçilik düzeylerinin avrupa birliği hayat boyu öğrenme projelerine yönelik tutumlarına etkisi. Electronic Journal of Social Sciences, 15(59), 1120-1134.

Ekşi, F. (2011). Kişisel gelişim literatürünün eğitim ve danışma ihtiyacı açısından incelenmesi:kuramsal analitik bir yaklaşım. Doktora tezi, Marmara Üniversitesi Eğitim Bilimleri Enstitüsü, İstanbul.

Foucault, M. (1999). Benlik teknolojileri. İçinde M. Foucault, H. Gutman ve P.H. Hutton (Eds). Kendini bilmek. (Ss. 22-75). İstanbul: Om.

Goldsmith, R.E., \& Foxall, G.R. (2003). The measurement of innovativeness in Larisa V. Shavinina (Ed). The international handbook on innovation (pp. 321-330). Canada: Pergamon.

Gündoğdu, F., ve Sunay, H. (2012). İnovasyon ve Türk spor yönetiminde inovasyon uygulamaları. Spormetre Beden Eğitimi ve Spor Bilimleri Dergisi, X(2), 61-66.

Hurt, H.T., Joseph, K., \& Cook, C.D. (1977). Scales for the measurment of innovativeness. Human Communication Research, 58-65.

Ivtzan, I., Chan, C.P.L., Gardner, H.E., \& Prashar, K. (2013). Linking religion and spirituality with psychological well-being: Examining self-actualization, meaning in life, and personal growth initiative. Journal of Religion and Health, 52(3), 915-929. 
Karadağ, T.F. (2018). Türkiye'deki spor federasyonları çalışanlarının örgütsel ögrrenme ve bireysel yenilikçilik profillerinin incelenmesi. Doktora Tezi, Gazi Üniversitesi Sağlık Bilimleri Enstitüsü, Ankara.

Kayabaş, B.K., ve Aydın, C.H. (2019). Kitlesel açık çevrimiçi derslere katılanların yenilikçilik profillerinin incelenmesi. Gümüşhane Üniversitesi Sosyal Bilimler Enstitüsü Elektronik Dergisi, 10(1), 1-17.

Karasar, N. (2016). Bilimsel Araştırma Yöntemi: Kavramlar İlkeler Teknikler. Nobel Akademik Yayıncılık: Ankara.

Kılıç, H. (2015). Illköğretim branş öğretmenlerinin bireysel yenilikçilik düzeyleri ve yaşam boyu öğrenme eğilimleri (Denizli ili örneği). Yüksek Lisans Tezi, Pamukkale Üniversitesi Eğitim Bilimleri Enstitüsü, Denizli.

Kılı̧, H., ve Tuncel, Z.A. (2014). Primary subject teachers' individual innovativeness levels and lifelong learning tendencies. Uluslararası Ĕ̆itim Programları ve Öğretim Çalışmaları Dergisi, 4(7), 25-37.

Kılıçer, E. (2011). Bilgisayar ve öğretim teknolojileri eğitimi öğretmen adaylarının bireysel yenilikçilik profilleri. Doktora tezi, Anadolu Üniversitesi Eğitim Bilimleri Enstitüsü, Eskişehir.

Kılıçer, K., ve Odabaşı, H.F. (2010). Bireysel yenilikçilik ölçeği (BYÖ): Türkçeye uyarlama, geçerlik ve güvenirlik çalışması. Hacettepe Üniversitesi Ĕ̈itim Fakültesi Dergisi, 38(38), 150-164.

Kılıçer, K., ve Odabaşı, H.F. (2013). Yenilikçiliğin önündeki engellerin araştırılması: Türkiye'deki teknoloji lideri öğretmen adaylarının görüşleri. Hacettepe Üniversitesi Ĕ̆itim Fakültesi Dergisi, 28(2), 246-265.

Korucu, A.T., ve Olpak, Y.Z. (2015). Öğretmen adaylarının bireysel yenilikçilik özelliklerinin farklı değişkenler açısından incelenmesi. Eğitim Teknolojisi Kuram ve Uygulama Dergisi, 5(1), 111-127.

Martin, H. M. (2009). Personal growth initiative as a moderator of expressive writing tasks: Test of a matching hypothesis. Master of arts, The Faculty of the Graduate School of The University of Maryland.

Muhammed, G. (2001). Spor ve kültürün kutsal kaynakları. İstanbul : İnsan.

Mülhim, M.A. (2018). Beden eğitimi ve spor yüksekokulu öğrencilerinin bireysel yenilikçilik düzeyleri ve yaşam boyu ögrenme eğilimlerinin incelenmesi: Bartın Üniversitesi örneği. Yüksek lisans tezi, Bartın Üniversitesi Eğitim Bilimleri Enstitüsü, Bartın.

Örün, Ö., Orhan, D., Dönmez, P., ve Kurt, A.A. (2015). Öğretmen adaylarının bireysel yenilikçilik profilleri ve teknoloji tutum düzeyleri arasındaki ilişkinin incelenmesi. Trakya Üniversitesi Ĕgitim Fakültesi Dergisi, $5(1), 65-76$.

Özata, F.Z. (2009). Yüksek teknoloji yeniliği olarak akıllı telefonların genç tüketiciler tarafindan benimsenmesinde etkili olan faktörler. Doktora tezi, Anadolu Üniversitesi Sosyal Bilimler Enstitüsü İşletme (Pazarlama) Anabilim Dalı, Eskişehir.

Özgür, H. (2013). Bilişim teknolojileri öğretmen adaylarının eleştirel düşünme eğilimleri ile bireysel yenilikçilik özellikleri arasındaki ilişkinin çeşitli değişkenler açısından incelenmesi. Mersin Üniversitesi Ĕ̆itim Fakültesi Dergisi, 9(2), 409-420.

Rimke, H.M. (2000). Governing citizens through self-help literature. Cultural studies, 14(1), 61-78.

Robitschek, C. (1998). Personal growth initiative: The construct and its measure. Measurement and Evaluation in Counseling and Development, 30(4), 183.

Robitschek, C. (1999). Further validation of the Personal Growth Initiative Scale. Measurement and Evaluation in Counseling and Development, 31, 197-210.

Robitschek, C. (2003). Validity of personal growth initiative scale scores with a mexican american college student population. Journal of Counseling Psychology, 50(4), 496-502. 
Robitschek, C., \& Keyes, C.L. (2009). Keyes's model of mental health with personal growth initiative as a parsimonious predictor. Journal of Counseling Psychology, 56(2), 321-329.

Rogers, E.M. (1995). Diffusion of innovation. New York: Free Press.

Rogers, E.M. ( 2003). Diffusion of innovations ( 5th ed.). New York: Free Press.

Söylev, Ö.F. (2016). Din hizmetlerinde inovasyon ve din görevlilerinin bireysel yenilikçilik özellikleri. Dokuz Eylül Ünivesitesi İlahiyat Fakültesi Dergisi, Özel Sayı: 115-147.

Şirin, T. (2005). Kişisel gelişim medeniyeti. İstanbul: Armoni.

Tat, M. (2007). Zihin dili programlaması (nlp) nın kişisel gelişim ve kişilerarası iletişim üzerindeki etkileri. Doktora tezi, Ege Üniversitesi Sosyal Bilimler Enstitüsü, İzmir.

Tırpan, M.S. (2016). Beden eğitimi ve spor yüksekokulu ögrencilerinin bireysel yenilikçilik ve genel özyeterlilikleri arasındaki ilişkinin incelenmesi. Yüksek lisans tezi, Ege Üniversitesi Sağlık Bilimleri Enstitüsü, İzmir.

Tırpan, M.S., ve Gençer, R.T. (2018). Beden eğitimi ve spor yüksekokulu öğrencilerinin bireysel yenilikçilik ve genel özyeterlilikleri arasındaki ilişkinin incelenmesi. Journal of Human Sciences, 15(4), 2144-2158.

Ünal, H. (2014). Üniversite öğrencilerinin bireysel yenilikçilik kategorilerinin belirlenmesi. Uluslararası Hakemli Akademik Spor Să̆llk ve Tip Bilimleri Dergisi, 11 (4), 68-74.

Wright, S.M., Levine, R.B., Beasley, B., Haidet, P., Gress, T.W., Caccamese, S., Brady, D.,Marwaha, A., \& Kern, D.E. (2006). Personal growth and its correlates during residency training. Medical education, 40(8), 737745 .

Yarım, D. (2004). Işsletme Çalışanlarında bireysel gelişim ve bir uygulama. Yüksek lisans tezi, Dumlupınar Üniversitesi Sosyal Bilimler Enstitüsü, Kütahya.

Yeğin, H.İ. (2017). İlahiyat fakültesi öğrencilerinin bireysel yenilikçilik düzeyleri. Abant İzzet Baysal Üniversitesi Sosyal Bilimler Enstitüsü Dergisi, 17(4), 239-262.

Y1lmaz Öztürk, Z., ve Summak, M. (2014). İlköğretim okulu öğretmenlerinin bireysel yenilikçiliklerinin incelenmesi. International Journal of Science Culture and Sport, 2(Special Issue 1), 844-853.

Yuan, F., \& Woodman, R.W. (2010). Innovative behavior in the workplace: The role of performance and image outcome expectations. Academy of Management Journal, 53(2), 323-342. 